\title{
Major and Trace Element Characterization of Shallow Groundwater in Coastal Alluvium of Chidambaram Town, Cuddalore District, South India
}

Thangasamy Jeyavel Raja Kumar, Chinadurai Dushiyanthan, Boopalan Thiruneelakandan, Radhakrishnan Suresh, Shanmugam Vasanth Raja, Mailare Senthilkumar

Department of Earth Sciences, Annamalai University, Chidambaram, India

Email: tjeyavel@rediffmail.com

Received 13 October 2015; accepted 10 January 2016; published 13 January 2016

Copyright (C) 2016 by authors and Scientific Research Publishing Inc.

This work is licensed under the Creative Commons Attribution International License (CC BY).

http://creativecommons.org/licenses/by/4.0/

c) (i) Open Access

\section{Abstract}

Hydrogeochemical investigation of groundwater of Chidambaram town has been carried out to assess the suitability for drinking uses and the source for the ions acquisition process. Geologically, the area comes under the alluvial zone and is followed by tertiary formation, includes sands, sand stone, laterite, clayey black and stiff clay. The water level varies from $6 \mathrm{~m}$ to $10 \mathrm{~m}$ bgl. Twenty groundwater samples are collected and analysed for $\mathbf{p H}$, Electrical Conductivity (EC), Total Dissolved Solids (TDS), major cations $\mathrm{Ca}^{2+}, \mathrm{Mg}^{2+}, \mathrm{Na}^{+}, \mathrm{K}^{+}$and anions $\mathrm{HCO}_{3}^{-}, \mathrm{Cl}^{-}, \mathrm{SO}_{4}^{-2}$. The trace elements of $\mathrm{Zn}, \mathrm{Pb}, \mathrm{Cr}, \mathrm{Fe}, \mathrm{Cd}, \mathrm{Cu}$ and $\mathrm{Mn}$ are determined. Study results reveal that groundwater in study area is a fresh water type. The $\mathrm{pH}, \mathrm{EC}$ and TDS are noticed high and sequence of abundance of the major ions is $\mathrm{Ca}^{2+}>\mathrm{Na}^{+}>\mathrm{Mg}^{2+}>\mathrm{K}^{+}$and $\mathrm{Cl}^{-}>\mathrm{SO}_{4}^{-2}>\mathrm{HCO}_{3}^{-}$. The Stufzand chloride classification indicates that the groundwater is derived from precipitations and Scholler classification shown type I. Hydrochemical facies of groundwater are $\mathrm{Ca}^{2+}>\mathrm{Na}^{+}>\mathrm{Cl}^{-}$and saturation index shows that nearly all the water samples are under saturated with respect to carbonate (calcite, dolomite and aragonite) and sulfate (gypsum and anhydrite) minerals. Except $\mathrm{Zn}$, other elements of $\mathrm{Fe}, \mathrm{Pb}$, $\mathrm{Cr}, \mathrm{Mn}, \mathrm{Cu}$, and $\mathrm{Cd}$ are found high and above the permissible limit of drinking water standard. The ionic concentration present in the groundwater of the study area can be from wastes of commercial activities, domestic sewage and automobiles rather than by ionic exchange and geological formation.

\section{Keywords}

Groundwater Quality, Hydrogeochemical Processes, Saturation Index, Trace Elements 


\section{Introduction}

Groundwater is a precious natural resource for several vital functions such as public, industries and agricultural water supply. In recent years, the quality of the groundwater is getting higher priority, due to the increasing trend of contamination level. At the same time, safe drinking water is a vital requirement to human being, and its availability is important for the overall socioeconomic development of a nation [1]. For the purpose of use, particularly drinking, determination of groundwater composition is of utmost importance from the point of view of its suitability. In common, rock water interaction, anthropogenic and industrial effluents are the primary source for groundwater composition and contamination; however, over exploitation of groundwater due to urbanization and addition of pollutants have rendered these resources to be useless in many instances. In addition to these processes water borne pathogens, toxic and nontoxic pollutants are the major water quality degradation parameters which are transported from recharge area to discharge area through aquifers by groundwater motion. In this scenario, it is essential that the study on quality of the groundwater is important not only for determining the level of concentration but also to learn about the contaminating sources of elements to the aquifers. In above all, undesirable and soluble constituents in the water cannot be controlled after entering the ground [2] [3]. Several comprehensive studies of groundwater contamination and sources have carried out in south India [4]-[7].

\subsection{Need of the Study}

In this study, an attempt has been made to understand the groundwater chemistry and quality of shallow aquifers of alluvium in Chidambaram town. The holy town Chidambaram has expanded very fast in the recent decades, and the running population also increased to worship and visit the temple. The requirement of fresh water has been increased, which drove to drill very deeper tube wells for the domestic usage due to most of the existing shallow tube wells of freshwater lens being dried during the summer season. The limited available quantity of potable water deteriorates due to salinity and pollution generated by sea water intrusion, agricultural activities in Chidambaram and its environs is at the verge of reaching an alarming situation [8]. Moreover, during the last decades, many cases of groundwater pollution in the coastal track due to seawater intrusion and anthropogenic inputs were reported [9] [10].

\subsection{Study Area}

The present study area Chidambaram town lies between longitude $79^{\circ} 40^{\prime}$ to $79^{\circ} 45^{\prime} \mathrm{E}$ and latitude $11^{\circ} 20^{\prime}$ to $11^{\circ} 25^{\prime} \mathrm{N}$ and located in the survey of India (SOI) topo sheet No. $58 \mathrm{M} / 15$ as shown in Figure 1. It is geographically located in the Cuddalore district of Tamil Nadu state, which is about $40 \mathrm{~km}$ east of Neyveli Lignite Mines, Neyveli. Geologically, the area comes under the alluvial zone which is the youngest in age and followed by tertiary formation, includes sands, sand stone, laterite, clayey black and stiff clay are pronominal (Figure 2). The water level varied from $6 \mathrm{~m}$ to $10 \mathrm{~m}$ bgl. The elevation is approximately about $+5.75 \mathrm{~m}$ above the mean sea level. The maximum and minimum temperature of the study area is $37.2^{\circ} \mathrm{C}$ and $21.6^{\circ} \mathrm{C}$. The precipitation recorded is mainly from the north east monsoon. The maximum and minimum rainfall received is $1400 \mathrm{~mm}$ and $1200 \mathrm{~mm}$. The higher rates of relative humidity (about 85\%) is observed during the north east monsoon period and in summer the relative humidity is low, about $60 \%$.

The occurrence of groundwater in the study area is on two formations, the unconsolidated Tertiary and Quaternary sediments. Fresh groundwater has been observed in the tertiary semi-consolidated sand stone and sands on the Cuddalore series. Most of the aquifers in the Cuddalore series are extensive and interconnected with aquifer above and below, and due to this water can move to greater distances through them. The transmissivity of the alluvium is $98 \mathrm{~m}^{2} / \mathrm{d}$ and permeability is $19.7 \mathrm{~m} / \mathrm{d}[11]$.

\section{Materials and Methods}

In order to understand the hydrogeochemistry and assess quality, twenty (20) tube well samples were collected (Figure 3) during the month of August, 2011 using standard procedure for the sampling techniques discussed by various authors [12] [13]. The analysis has been carried out in the Department of Earth Sciences, Annamalai University for $\mathrm{pH}$, Electrical Conductivity (EC), Total Dissolved Solids (TDS), major cations $\mathrm{Ca}^{2+}, \mathrm{Mg}^{2+}, \mathrm{Na}^{+}$, $\mathrm{K}^{+}$and anions $\mathrm{HCO}_{3}^{-}, \mathrm{Cl}^{-}, \mathrm{SO}_{4}^{-2}$. 


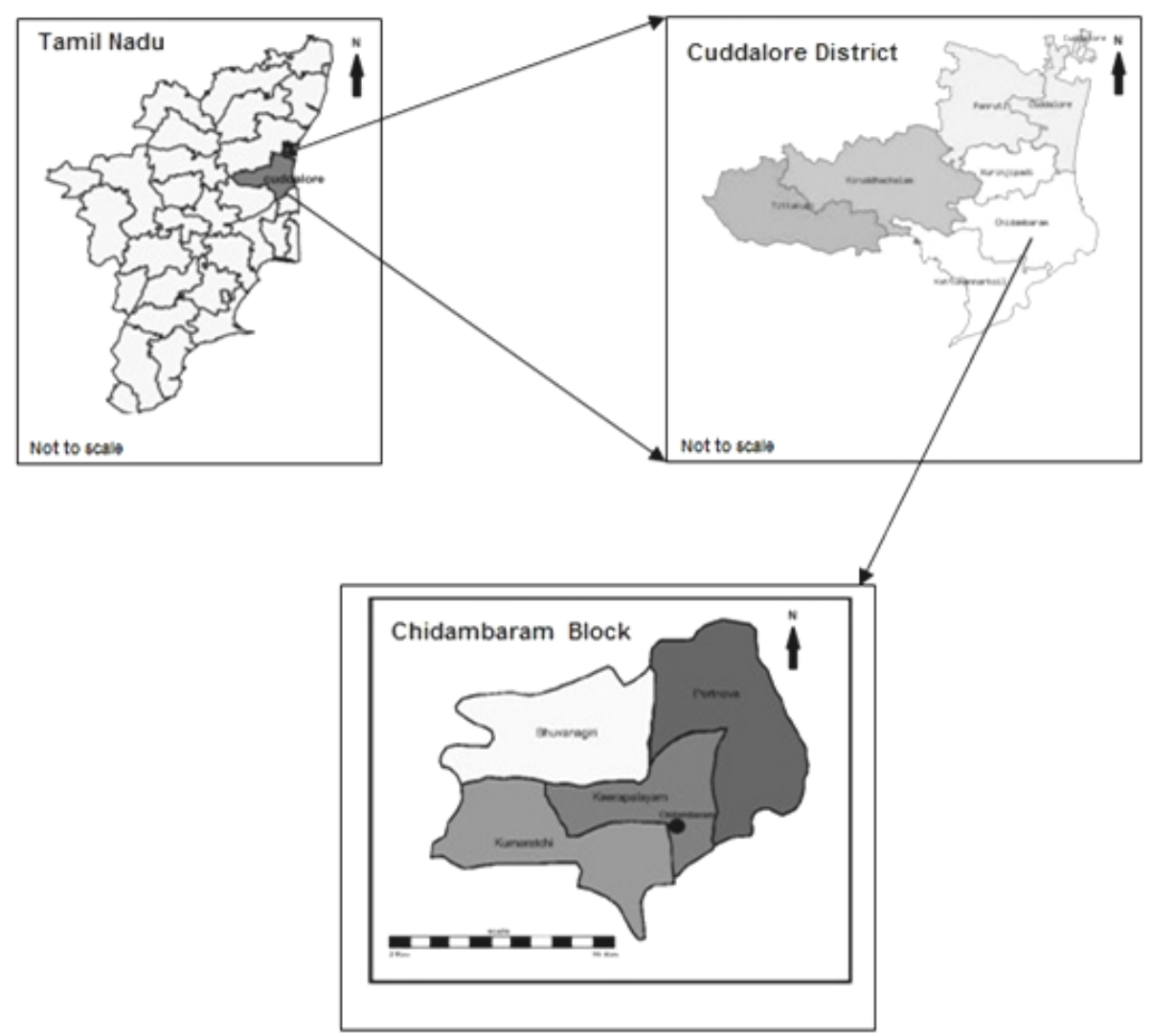

Figure 1. Location map of the study area.

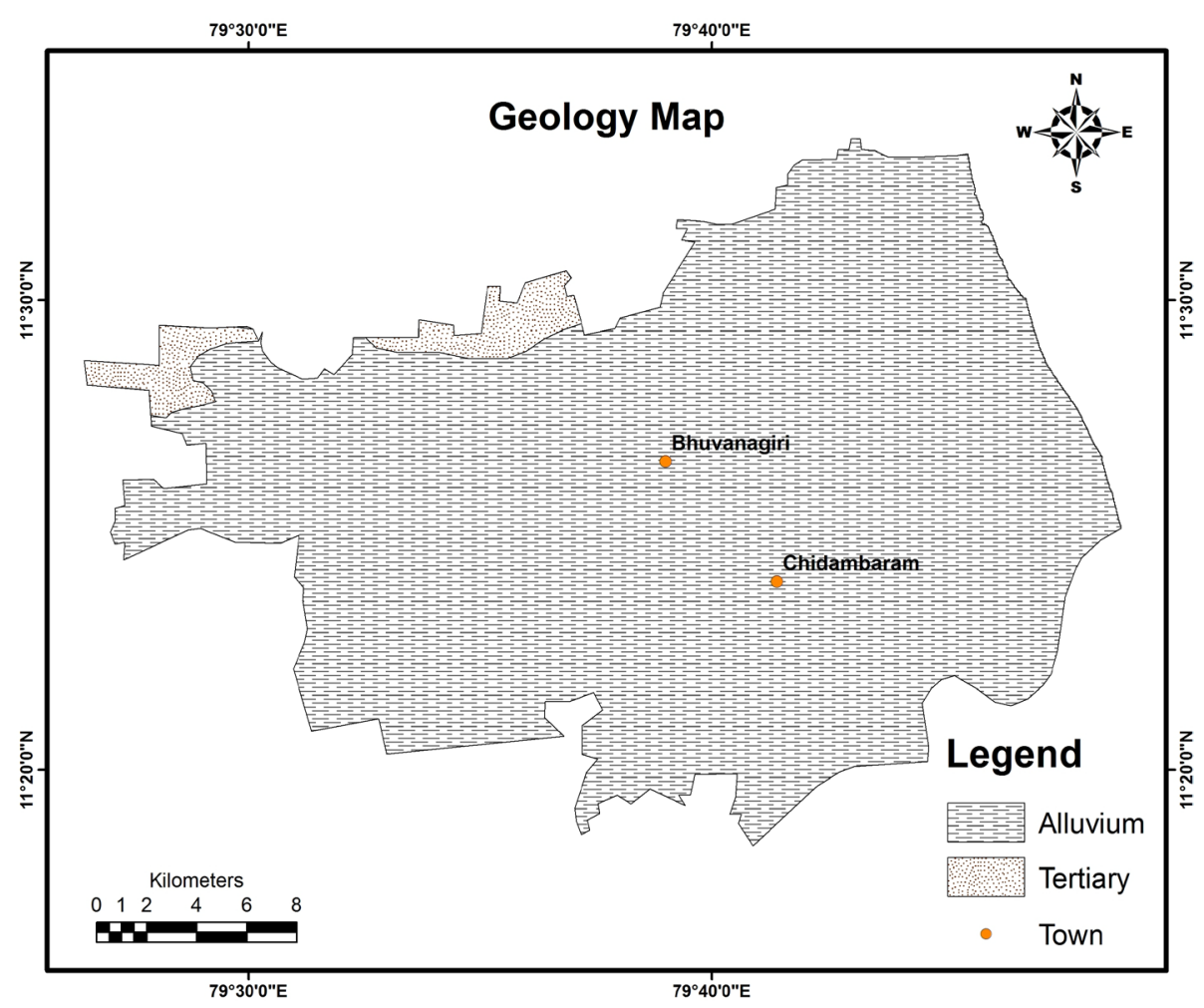

Figure 2. Geology map of the study area. 


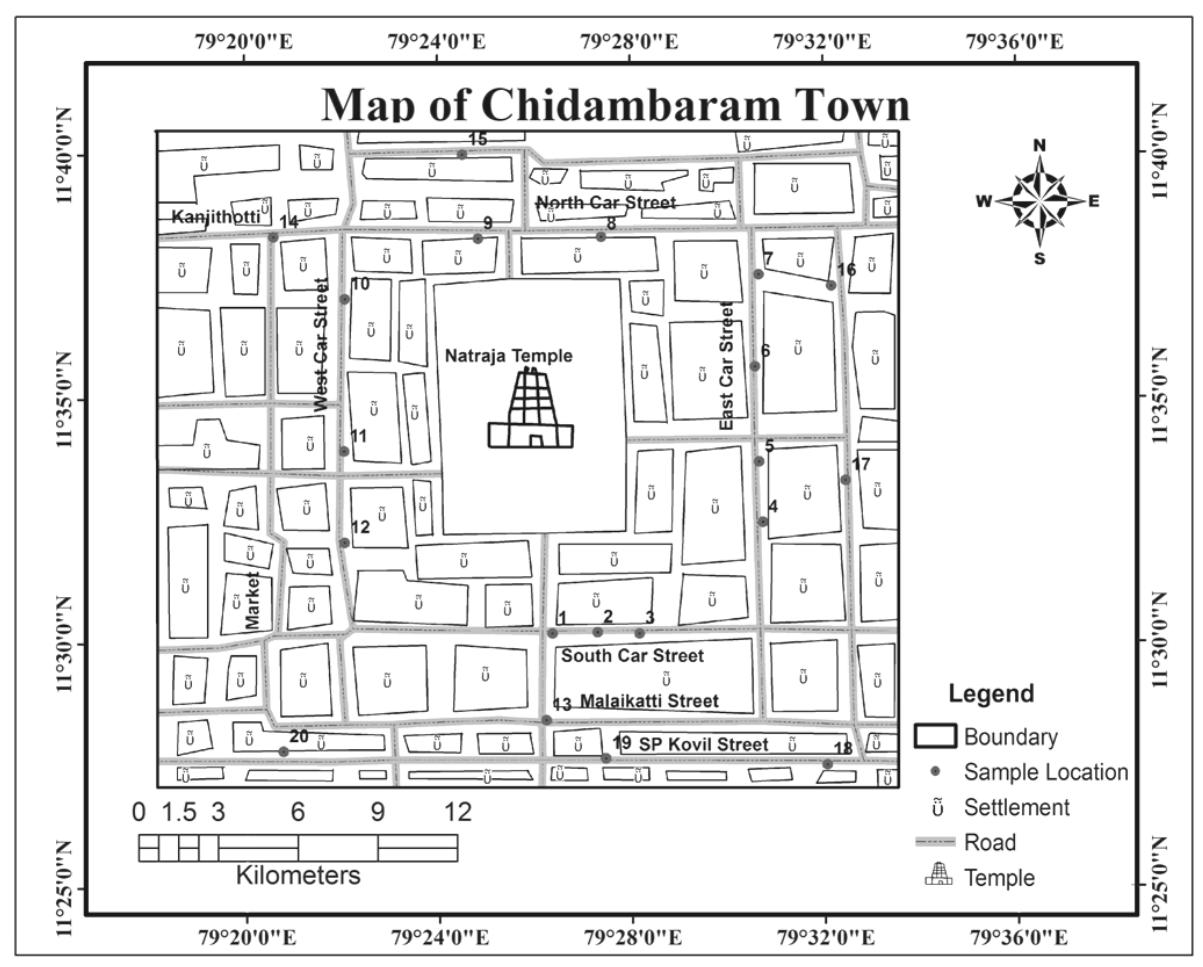

Figure 3. Sample location map.

\section{Analytical Techniques}

In the present study, the $\mathrm{pH}$ was measured using the instrument model Systronic-335. The TDS was measured using Weight Balance Schimedge T423l muffle furnace technique, and the EC was measured using the model Systronic-304. The $\mathrm{Ca}^{2+}, \mathrm{Mg}^{2+}$ and $\mathrm{HCO}_{3}^{-}, \mathrm{Cl}^{-}$, were measured by the volumetric method whereas the $\mathrm{Na}^{+}, \mathrm{K}^{+}$ was measured using flame photo meter model CL 378. Further, the $\mathrm{SO}_{4}^{-2}$ was measured using spectro photometer model SL-171 minispec. Except pH, other parameters are expressed in $\mathrm{Mg} / \mathrm{L}$ whereas the EC value is expressed in mohs $/ \mathrm{cm}$ at $25^{\circ} \mathrm{C}$. The trace elements of $\mathrm{Zn}, \mathrm{Pb}, \mathrm{Cr}, \mathrm{Fe}, \mathrm{Cd}, \mathrm{Cu}$ and $\mathrm{Mn}$ were determined using AAS model Elico-SL-176. The data of major ions has analysed and interpreted using software WATCLAST [14]. The groundwater sample analysis data of the study area is presented in Table 1. Similar studies have carried out extensively by many authors on groundwater quality [15]-[18].

\section{Results and Discussion}

\subsection{General Hydrogeochemistry}

The collected groundwater samples shown colourless in most of the locations and few samples were shown pale yellowish colour. The yellowish colour of the samples is due to the presence of suspended solids and silts. Analytical results indicate that $\mathrm{pH}$ of groundwater in the study area ranges from 7.1 to 8.6. It is observed that all the samples are above the permissible limit of 6.5, and within the desirable limit of 8.5 suggested by World Health Organization [19] standard for drinking. The $\mathrm{pH}$ of the water is influenced by atmospheric contribution, decomposition of organic matter and anthropogenic causes.

Electrical Conductivity (EC) and Total Dissolved Solids (TDS) of the groundwater varies from 171 to 6358 microsimens $/ \mathrm{cm}$ at $25^{\circ} \mathrm{C}$ and $386.3 \mathrm{mg} / \mathrm{L}$ to $1491 \mathrm{mg} / \mathrm{L}$ respectively. The EC observed to exceed the permissible limit of 750 microsimens/cm (WHO, 2006) in 16 locations. TDS found above the permissible limit of $500 \mathrm{mg} / \mathrm{L}$ in 11 locations and above the excessive limit of $1000 \mathrm{mg} / \mathrm{L}$ in 5 locations. Generally, water containing more than $500 \mathrm{mg} / \mathrm{L}$ of total dissolved solids is not considered potable. However, it is observed that highly mineralized water is also used in the absence of quality water. According to Freeze and Cherrry [20] classification, 15 samples are fresh water category (TDS $<1000 \mathrm{mg} / \mathrm{L}$ ) and 5 samples are brackish water category (TDS >1000 mg/L). 
Table 1. Analyzed hydrogeochemical parameters of groundwater of the study area.

\begin{tabular}{|c|c|c|c|c|c|c|c|c|c|c|c|c|c|c|c|c|c|c|}
\hline S.No & $\mathrm{Ca}^{2+}$ & $\mathrm{Mg}^{2+}$ & $\mathrm{Na}^{+}$ & $\mathrm{K}^{+}$ & $\mathrm{Cl}^{-}$ & $\mathrm{HCO}_{3}^{-}$ & $\mathrm{SO}_{4}^{-2}$ & $\mathrm{pH}$ & EC & TDS & SAR & $\mathrm{Zn}$ & $\mathrm{Pb}$ & $\mathrm{Cr}$ & $\mathrm{Fe}$ & $\mathrm{Cd}$ & $\mathrm{Cu}$ & $\mathrm{Mn}$ \\
\hline 1 & 67.6 & 51.7 & 38.5 & 8.4 & 62 & 47.2 & 37.5 & 7.4 & 1875 & 965 & 1.092 & 0.09 & 1.09 & 0.77 & 0.61 & 0.02 & 2.12 & 0.26 \\
\hline 3 & 74.4 & 42.5 & 38.5 & 6.4 & 91 & 71.5 & 29.1 & 8.1 & 1414 & 805 & 0.992 & 0.03 & 0.83 & 1.1 & 0.91 & $\mathrm{BD}$ & 2.24 & 0.26 \\
\hline 4 & 65.1 & 51.9 & 43.6 & 5.2 & 91 & 39.6 & 26.3 & 8.1 & 1231 & 750 & 1.078 & 0.01 & 0.06 & 0.45 & 0.76 & 0.02 & 1.94 & 0.33 \\
\hline 5 & 94.7 & 32.5 & 41.5 & 7.6 & 122 & 56.2 & 45.6 & 7.8 & 263 & 1491 & 0.761 & 0.06 & 0.32 & 0.77 & 0.76 & 0.02 & 2.35 & 0.12 \\
\hline 6 & 71.8 & 51.6 & 42.9 & 3.3 & 58 & 41.2 & 30.8 & 8.1 & 786 & 463 & 4.992 & 0.05 & 1.09 & 0.45 & 0.16 & 0.07 & 0.59 & 0.04 \\
\hline 7 & 68.8 & 85.5 & 41.9 & 3.3 & 64 & 39.5 & 26.8 & 8.1 & 1072 & 620 & 3.414 & 0.06 & 0.83 & 0.13 & 0.76 & 0.02 & 1.12 & 0.12 \\
\hline 8 & 64.5 & 21.5 & 42.5 & 2.9 & 58 & 21.5 & 45.2 & 8.1 & 6358 & 386 & 6.575 & 0.05 & 0.83 & 0.19 & 0.16 & 0.05 & 1.24 & 0.12 \\
\hline 10 & 74.2 & 92.5 & 38.5 & 6.3 & 91 & 24.7 & 34.5 & 8.5 & 766 & 412 & 3.566 & 0.06 & 0.83 & 0.52 & 0.46 & 0.05 & 1.18 & 0.19 \\
\hline 11 & 71.2 & 47.2 & 61.5 & 7.1 & 127 & 54.2 & 53.1 & 8.0 & 1793 & 753 & 3.307 & 0.13 & 1.09 & 0.84 & 0.61 & 0.02 & 1.71 & 0.26 \\
\hline 12 & 73.2 & 56.5 & 41.5 & 6.4 & 81 & 41.5 & 24.1 & 8.0 & 1301 & 987 & 3.926 & 0.11 & 0.46 & 0.84 & 1.21 & $\mathrm{BD}$ & 1.77 & 0.19 \\
\hline 13 & 66.4 & 56.9 & 40.7 & 8.5 & 52 & 54.5 & 48.1 & 8.0 & 171 & 978 & 4.147 & 0.06 & 0.2 & 1.16 & 0.91 & BD & 1.88 & 0.12 \\
\hline 14 & 74.9 & 74.2 & 87.5 & 6.3 & 113 & 51.5 & 48.4 & 8.1 & 1618 & 878 & 3.814 & 0.06 & 0.06 & 1.48 & 0.91 & 0.02 & 2.06 & 0.26 \\
\hline 15 & 68.4 & 71.9 & 41.7 & 5.8 & 101 & 23.9 & 22.5 & 8.6 & 728 & 451 & 4.855 & 0.09 & 0.32 & 1.16 & 0.91 & BD & 2.06 & 0.19 \\
\hline 16 & 72.5 & 65.5 & 86.5 & 10.2 & 136 & 85.5 & 12.4 & 7.9 & 2318 & 1385 & 3.276 & 0.09 & 0.32 & 1.81 & 1. 36 & 0.02 & 1.94 & 0.26 \\
\hline 17 & 70.2 & 48.8 & 101.5 & 10.4 & 139 & 69.7 & 25.7 & 7.1 & 243 & 1263 & 3.793 & 0.09 & 0.57 & 1.48 & 1.21 & 0.02 & 2.06 & 0.26 \\
\hline 19 & 69.4 & 36.5 & 95.3 & 2.6 & 123 & 41.7 & 38.5 & 8.0 & 1012 & 579.4 & 3.904 & 0.08 & 0.32 & 1.48 & 1.51 & 0.02 & 1.06 & 0.4 \\
\hline 20 & 65.1 & 38.5 & 71.5 & 7.9 & 113 & 51.5 & 32.6 & 8.0 & 1732 & 1097 & 3.948 & 0.1 & 0.32 & 1.81 & 0.91 & 0.05 & 2.06 & 0.4 \\
\hline
\end{tabular}

* Except pH, EC, and SAR others are expressed in $\mathrm{mg} / \mathrm{L}$. EC is in microsiemens/cm at $25^{\circ} \mathrm{C}$.

\subsection{Major Cations Chemistry}

The $\mathrm{Ca}^{2+}$ ionic concentration is found to be low as $64.5 \mathrm{mg} / \mathrm{L}$ in location 8 whereas it is observed as high concentration of $94.7 \mathrm{mg} / \mathrm{L}$ in location 5. The permissible limit of $\mathrm{Ca}^{2+}$ for drinking water is specified as $75 \mathrm{mg} / \mathrm{L}$ (WHO, 2006) and except sample number 5, all other samples are within the permissible limit. The $\mathrm{Mg}^{2+}$ concentration varies from $21.5 \mathrm{mg} / \mathrm{L}$ to $92.5 \mathrm{mg} / \mathrm{L}$ and the limit of $\mathrm{Mg}^{2+}$ for drinking water is $30 \mathrm{mg} / \mathrm{L}$ (WHO, 2006), and except sample number 8, all other are above the permissible limit. The high concentration of $\mathrm{Mg}^{2+}$ is observed in location number 10 whereas, low concentration is observed in sample location 8 . The $\mathrm{Na}^{+}$concentration varies from $28.9 \mathrm{mg} / \mathrm{L}$ to $101.5 \mathrm{mg} / \mathrm{L}$. The permissible limit of $\mathrm{Na}^{+}$for drinking water is specified as 200 $\mathrm{mg} / \mathrm{L}$ (WHO, 2006), and all are within the permissible limit. The higher value is observed in locations 17 and low value is noticed in locations 2 . The $\mathrm{K}^{+}$concentration varies from $2.6 \mathrm{mg} / \mathrm{L}$ to $10.4 \mathrm{mg} / \mathrm{L}$. The permissible limit of $\mathrm{K}^{+}$for drinking water is specified as $50 \mathrm{mg} / \mathrm{L}$ (WHO, 2006) and all samples are below the permissible limit. The higher value of $10.4 \mathrm{mg} / \mathrm{L}$ is observed in location 19 and low value of $2.6 \mathrm{mg} / \mathrm{L}$ noticed in location 17 .

Generally, concentration of $\mathrm{Ca}^{2+}, \mathrm{Mg}^{2+}, \mathrm{Na}^{+}$in the groundwater from clay minerals such as montmorillionite, illeite and chlorite [21]. In this area, $\mathrm{Na}^{+}$and $\mathrm{K}^{+}$ions present relatively higher concentrations in groundwater is particularly derived from leaching of clay minerals, gypsum and anhydrites, whereas the calcium ion is also derived from cation exchange process. Sodium has its source from silicate minerals, atmospheric precipitation and halite deposits. In the study, the major concentrations except $\mathrm{Mg}^{2+}$ are low and below the permissible limit of the standards for drinking water. Since the level of concentration is very low, the source could be from cation ex- 
change process and from pollution sources, which have the indication of $\mathrm{Na} / \mathrm{Cl}$ ratio $>1$. Sewage, industrial effluents, the use of sodium compounds for corrosion control and water softening process have contributed to $\mathrm{Na}^{+}$ concentration in groundwater of the study area.

\subsection{Major Anions Chemistry}

The Bicarbonate concentration varies from $21.5 \mathrm{mg} / \mathrm{L}$ to $85.5 \mathrm{mg} / \mathrm{L}$. The $\mathrm{HCO}_{3}^{-}$concentration is rather high in location number 16, and it is observed low in location number 8 . The $\mathrm{Cl}^{-}$concentration varies from $52 \mathrm{mg} / \mathrm{L}$ to $141 \mathrm{mg} / \mathrm{L}$. The permissible limit of $\mathrm{Cl}^{-}$concentration for drinking water is specified as $250 \mathrm{mg} / \mathrm{L}$ and excessive limit of $1000 \mathrm{mg} / \mathrm{L}$ (WHO, 2006). All samples are within the permissible limit and high concentration of $\mathrm{Cl}^{-}$is noticed in location number 18 whereas low concentration is found in sample location $2 \& 13$. The Sulphate concentration is found varying from $12.4 \mathrm{mg} / \mathrm{L}$ to $53.1 \mathrm{mg} / \mathrm{L}$. The permissible limit for drinking water is specified as $200 \mathrm{mg} / \mathrm{L}$ (WHO, 2006) and all are within the permissible limit.

The major source, however, is due to chemical weathering of rocks, whereas most of the pollutants could be of anthropogenic origin. All rocks do not weather at the same rate. Sulfate ion concentrations are probably derived from weathering of sulfate and gypsum bearing sedimentary rocks [5] [6]. The most significant source of sulphate is rock weathering and pollution. Dissolved sulphate has its origin from dissolution of gypsum, oxidation of pyrites and contaminated sulphate from industrial discharges. Sulphate is also a major constituent in the aerosols which is from smoke coming from industries and automobiles. In the study area, higher sulfate might have also been derived from the leaching of the evaporate sediments rich in gypsum abhydrite and sodium sulfate [8]. Health concerns regarding sulphates in drinking water have been raised because of reports of diarrhea associated with ingestion of water with high levels of sulphates [22].

\subsection{Quality of Groundwater Based on Chloride}

High concentration of chloride gives an undesirable taste to water. Infants and children may suffer if they consume water high in chloride as their tissues may be damaged by the high osmotic pressure brought about by the presence of high concentration of salts. In drinking water, chloride concentration above $250 \mathrm{mg} / \mathrm{L}$ causes on objectionable salty taste and makes a deleterious effect on metallic pipes, structures and agriculture crops.

To assess the water based on Chloride, Stuyfzand [23] classification is widely followed and has been classified into 8 main types as given below:

\begin{tabular}{ccc}
\hline Chloride type & Cl concentration in epm & Number of samples \\
\hline Extremely Fresh & $<0.141$ & Nil \\
Very Fresh & $0.141-0.846$ & Nil \\
Fresh & $0.846-4.231$ & 05 \\
Fresh Brackish & $4.321-8.462$ & 09 \\
Brackish & $8.462-28.206$ & 06 \\
Brackish-Salt & $28.206-282.064$ & Nil \\
Salt & $282.064-564.127$ & Nil \\
Hyperhaline & $>564.127$ & Nil \\
\hline
\end{tabular}

It is observed that the most of the samples were fell in fresh to fresh brackish water category. The brackish water type shown in six locations and it could be mixing of in situ saline water from bottom aquifers. Hence, the water could have infiltrated from recent precipitation and level of concentration may increase from marine sediments water interaction by means of gradual ionic exchange.

\subsection{Schoeller Classification}

Schoeller [12] proposed a water type classification based on the concentration of groundwater within the sub 
surface which is as follows:

$$
\mathrm{rHCO}_{3}>\mathrm{rSO}_{4} \text {----------Type I }(\mathrm{r}=\mathrm{epm})
$$

as the duration of stay increases, the above relation changes to

$$
\mathrm{rSO}_{4}>\mathrm{rHCO}_{3}--------- \text { Type II }
$$

with further increase of duration, the ionic concentration changes to

$$
\mathrm{rCl}>\mathrm{rSO}_{4}>\mathrm{rHCO}_{3} \text {---------Type III }
$$

in the final stage the ionic concentration reaches

$$
\begin{aligned}
\mathrm{rCl} & >\mathrm{rSO}_{4}>\mathrm{r} \mathrm{HCO}_{3} \text { along with } \\
\mathrm{rNa} & >\mathrm{rMg}>\mathrm{rCa}---------- \text { Type IV }
\end{aligned}
$$

The changes from type I to type IV depend on the residence time of water in the subsurface and the extent of rock water interaction.

The samples collected from present study area demonstrate that all the 20 groundwater samples have come under the water type I. As the present study was carried out in shallow level aquifers, it is observed that the strata sediment characterization and interaction are responsible for the present level of concentration in the groundwater. In general, the saturated thickness of groundwater could be maintained for certain level in the subsurface lithounits due to hydrostatic pressure, which could lead to release of soluble elements and responsible for the present ionic concentration in groundwaters.

\subsection{Chemical Relationship}

Piper's Trilinear diagrams are very useful in bringing out the chemical relationships of ground waters in more definite terms [24]. It identifies hydrochemical facies by plotting the chemical composition of water in a central diamond-shaped diagram in which all the four sides are defined by the proportions of major ions in water. In the present study, the major cations and anions of water samples have been plotted with Piper Trilinear diagram [25] and is shown in Figure 4. The plotted samples were distributed in sector 6 of the diamond-shaped field which indicates that Non-carbonate exceeds 50\%. The hydrogeochemical facies of the water samples are as $\mathrm{Ca}^{2+}>\mathrm{Na}^{+}$ and $\mathrm{Cl}^{-}>\mathrm{SO}_{4}^{2-}$ facies.

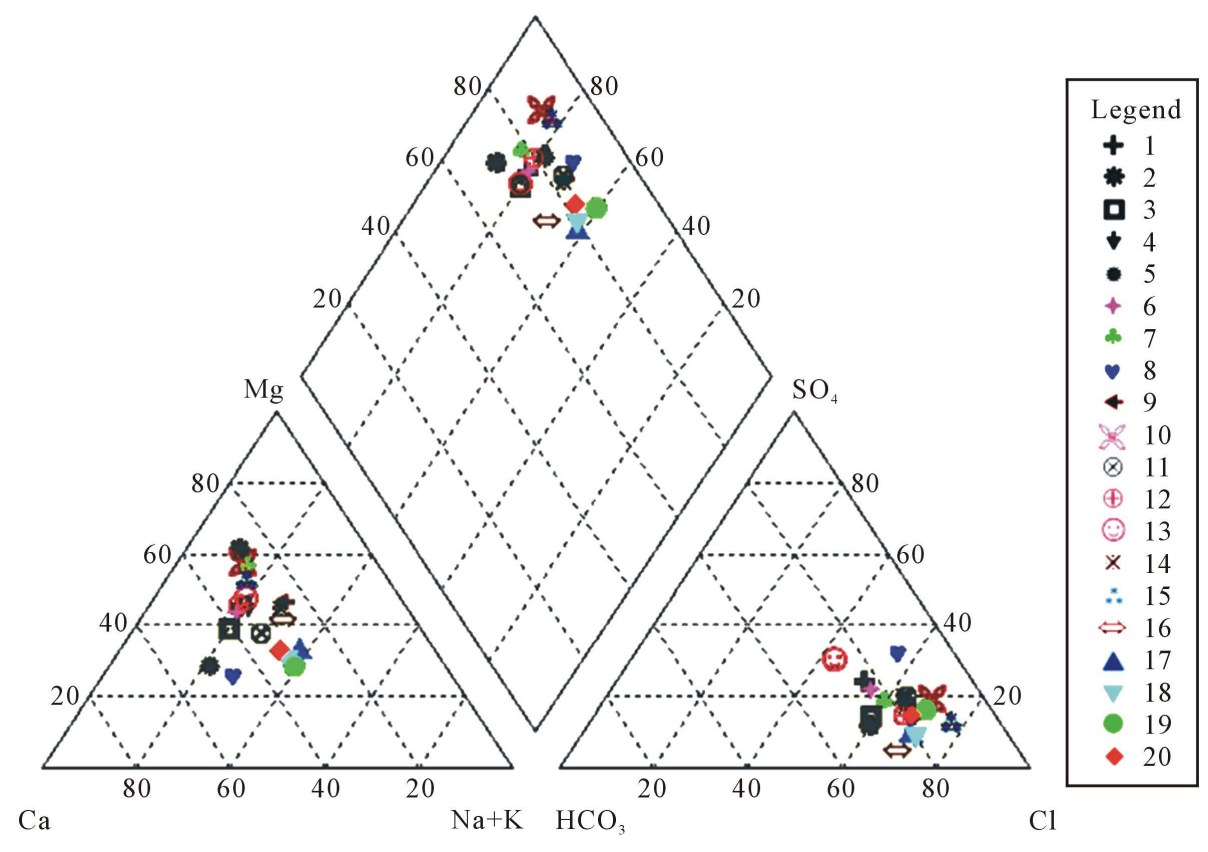

Figure 4. Piper plot. 


\subsection{Corrosivity Ratio}

Corrosivity Ratio is defined as the corrosive tendency of water due to the proportional occurrence of alkaline earths and saline salts along with sulphides in the composition of the water. [17] [26] [27] have used the ratio to evaluate corrosive tendency of groundwater on metallic pipes of various regions. According to Balasubramanian [28] the corrosivity value less than one is considered to be safe for transport of water in any pipe. Similarly, corrosivity higher than one is to as not safe for transport of water. The effects of corrosion are losses in hydraulic capacity of pipes. It is observed that 15 samples were greater than 1.0 and hence the study area groundwater cannot be transported through the pipe for drinking purpose for long duration activities. The release on ions from the flow path lithology and anthropogenic could be the main feeder into the groundwater.

\subsection{Saturation State}

Saturation indexes are used to evaluate the degree of equilibrium between water and minerals. It is a convenient parameter to evaluate the proximity to equilibrium for various solubility reactions, describing the tendency of the solution to dissolve or precipitate a set of minerals [29]. Changes in the saturation state are useful to distinguish different stages of hydrochemical evolution and help identify which geochemical reactions are important in controlling water chemistry [29]-[31]. The saturation index of a mineral is obtained from equation SI $=\log$ (IAP/Kt) where the IAP is the ion-activity product of the mineral-water reaction, and $\mathrm{Kt}$ is the thermodynamic equilibrium constant. The saturation for a mineral is indicated when the SI is between -1.0 and +1.0 . The index describes the deviation of water from equilibrium with respect to dissolved minerals quantitatively [32] [33]. If the SI is greater than zero, a state of saturation or super saturation is achieved, and minerals would precipitate. If SI is less than zero it means the conditions for mineral dissolution are achieved. The SI around zero indicates equilibrium conditions; therefore, dissolution or precipitation of a certain mineral phase controls the level of the dissolved components contained in that phase.

In this study saturation index has been studied for the Calcite and Sulphate minerals as shown in Figure 5. The Calcite group consisting of Magnesite, Dolomite, Calcite and Aragonite and Sulphate group consisting of Aragonite and Gypsum minerals. The index of both the calcite and sulphate minerals are undersaturated state. It indicates the insufficient amount of the mineral for solution or short residence time.

\section{Trace Elements}

Early concerns over the quality of groundwaters were focused mainly on dissolved mineral salts. However, recently, organics, heavy and trace metals have become a focus of concern for several reasons, including enhanced ability to detect chemicals in the microgram and nano gram per liter concentration levels and an increasing awareness of potentially hazardous risks to public health and the environment. Many trace elements are essential nutrients however certain trace elements such as As, Cd, and Hg are known to be persistent environment contamination and toxic to most form of life. Trace elements are generally present in small concentration in the natural water system. Trace elements are contributed to groundwater from a variety of natural and anthropogenic sources. Once liberated to groundwater, element distributions are continually modified by complex geochemical and biological processes [34].

The trace element data may help to assess the level of heavy metal concentration in groundwater of the study area and possible source. Selected trace metals of $\mathrm{Fe}, \mathrm{Pb}, \mathrm{Cr}, \mathrm{Mn}, \mathrm{Cu}, \mathrm{Zn}$ and $\mathrm{Cd}$ were studied in groundwater samples of the study area. The minimum and maximum of trace elements of the analysed groundwater samples of the study area is given in Table 2 and also the variation is presented as a graph in Figure 6.

\subsection{Iron (Fe)}

Fe is presented in fully aerated water of normal $\mathrm{pH}$ in small amounts (as $0.5 \mathrm{mg} / \mathrm{L}$ ) and acid water may contain ferric iron in large amounts. Microorganisms are causes for dissolving and precipitating iron from water. Rarly, the concentration over $50 \mathrm{mg} / \mathrm{L}$ may occur in waters with a $\mathrm{pH}$ of 5 to 8 and concentration upto $10 \mathrm{mg} / \mathrm{L}$ is uncommon. Morethan about $0.5 \mathrm{mg} / \mathrm{L}$ stains clothes and utensils. Iron is objectionable in food processing industry [35]. In the study area, Fe concentration varied from 0.16 to $1.51 \mathrm{mg} / \mathrm{L}$ where the higher concentration found in location 19 and low in location 6 . The standard for the drinking is $0.3 \mathrm{mg} / \mathrm{L}$ where 18 locations are found above the permissible limit and in locations 12, 16, 17, 18 \& 19 are found the excessive limit of $1 \mathrm{mg} / \mathrm{L}$. The high 
Table 2. Comparison with drinking water standards.

\begin{tabular}{|c|c|c|c|c|c|c|c|c|c|}
\hline \multirow{2}{*}{ Paramters } & \multirow{2}{*}{ Min } & \multirow{2}{*}{ Max } & \multirow{2}{*}{ Mean } & \multicolumn{2}{|c|}{ WHO, 2006} & \multirow{2}{*}{$\begin{array}{c}\text { Above } \\
\text { permissible } \\
\text { limit }\end{array}$} & \multicolumn{2}{|c|}{ BIS, 2003} & \multirow{2}{*}{$\begin{array}{c}\text { Above } \\
\text { permissible } \\
\text { limit }\end{array}$} \\
\hline & & & & Permissible & Excessive & & Desirable & Permissible & \\
\hline $\mathrm{pH}$ & 7.1 & 8.6 & 7.9 & $7.0-8.5$ & $>8.5$ & 2 & 6.5 & 8.5 & 2 \\
\hline EC & 171 & 6358 & 1672 & 750 & - & 17 & 500 & - & 17 \\
\hline TDS (mg/L) & 386 & 1491 & 867 & 500 & 1000 & 16 & 500 & 2000 & 16 \\
\hline Calcium $\left(\mathrm{Ca}^{2+}\right)(\mathrm{mg} / \mathrm{L})$ & 64.5 & 94.7 & 71.9 & 75 & 100 & 01 & 75 & 200 & Nil \\
\hline Magnesium $\left(\mathrm{Mg}^{2+}\right)(\mathrm{mg} / \mathrm{L})$ & 21.5 & 92.5 & 57.0 & 30 & 100 & 19 & 30 & 100 & Nil \\
\hline Sodium $\left(\mathrm{Na}^{+}\right)(\mathrm{mg} / \mathrm{L})$ & 28.9 & 101.5 & 58.8 & 200 & - & Nil & - & 200 & Nil \\
\hline Potassium $\left(\mathrm{K}^{+}\right)(\mathrm{mg} / \mathrm{L})$ & 2.6 & 10.4 & 6.4 & 50 & 150 & Nil & - & - & \\
\hline Sulphate $\left(\mathrm{SO}_{4}^{-2}\right)(\mathrm{mg} / \mathrm{L})$ & 12.4 & 53.1 & 33.1 & 200 & 400 & Nil & 200 & 400 & Nil \\
\hline Chloride $\left(\mathrm{Cl}^{-}\right)(\mathrm{mg} / \mathrm{L})$ & 52 & 141 & 97.6 & 250 & 1000 & Nil & 250 & 1000 & Nil \\
\hline $\mathrm{Zn}$ & 0.01 & 0.13 & 0.07 & 5 & 15 & & & & \\
\hline $\mathrm{Pb}$ & 0.06 & 1.09 & 0.57 & NA & 0.05 & & & & \\
\hline $\mathrm{Cr}$ & 0.13 & 1.81 & 0.94 & NA & 0.05 & & & & \\
\hline $\mathrm{Fe}$ & 0.16 & 1.51 & 0.79 & 0.3 & 1.0 & & & & \\
\hline $\mathrm{Cd}$ & $\mathrm{BD}$ & 0.07 & 0.02 & 0.01 & 0.01 & & & & \\
\hline $\mathrm{Cu}$ & 0.59 & 2.35 & 1.7 & 0.05 & 1.5 & & & & \\
\hline $\mathrm{Mn}$ & 0.04 & 0.4 & 0.22 & 0.05 & 0.5 & & & & \\
\hline
\end{tabular}
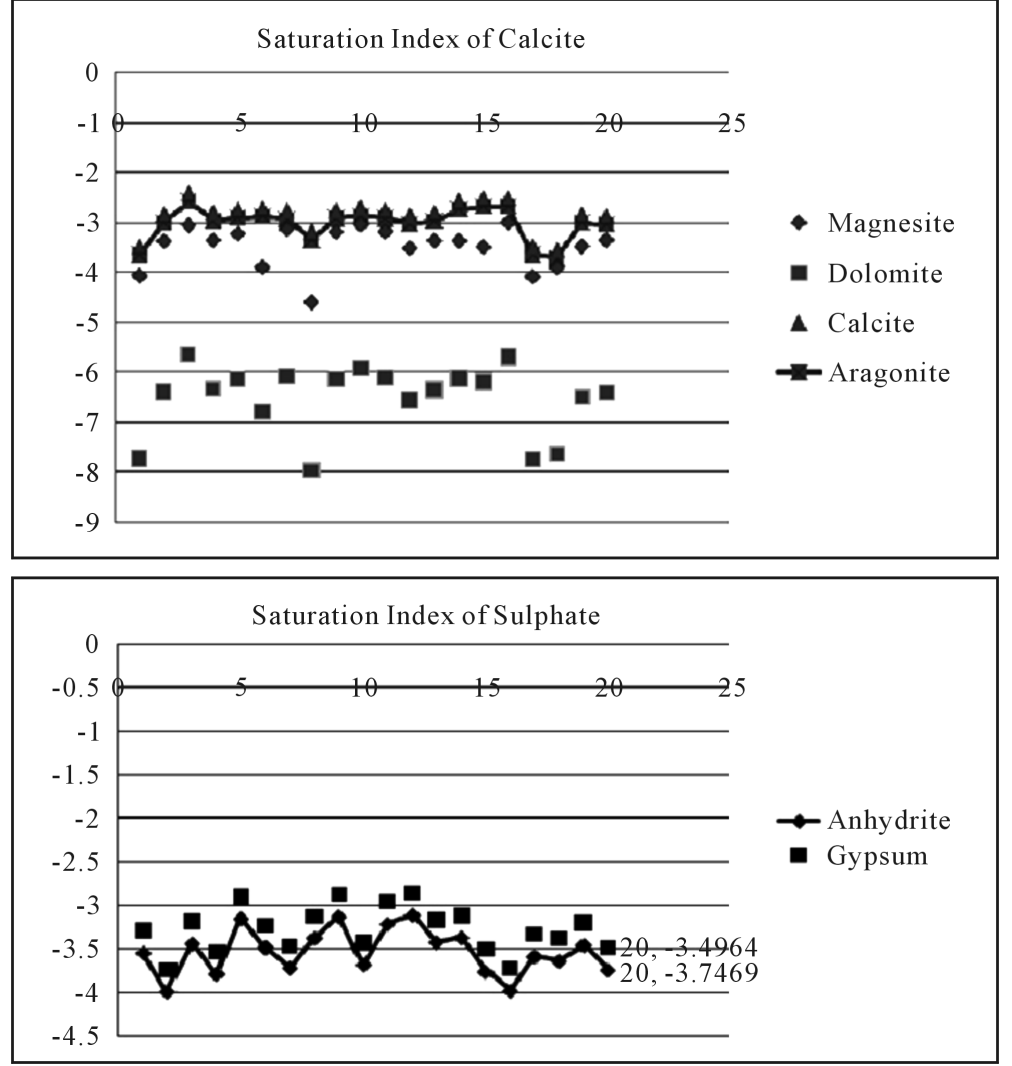

Figure 5. Saturation index of calcite and sulphate minerals. 


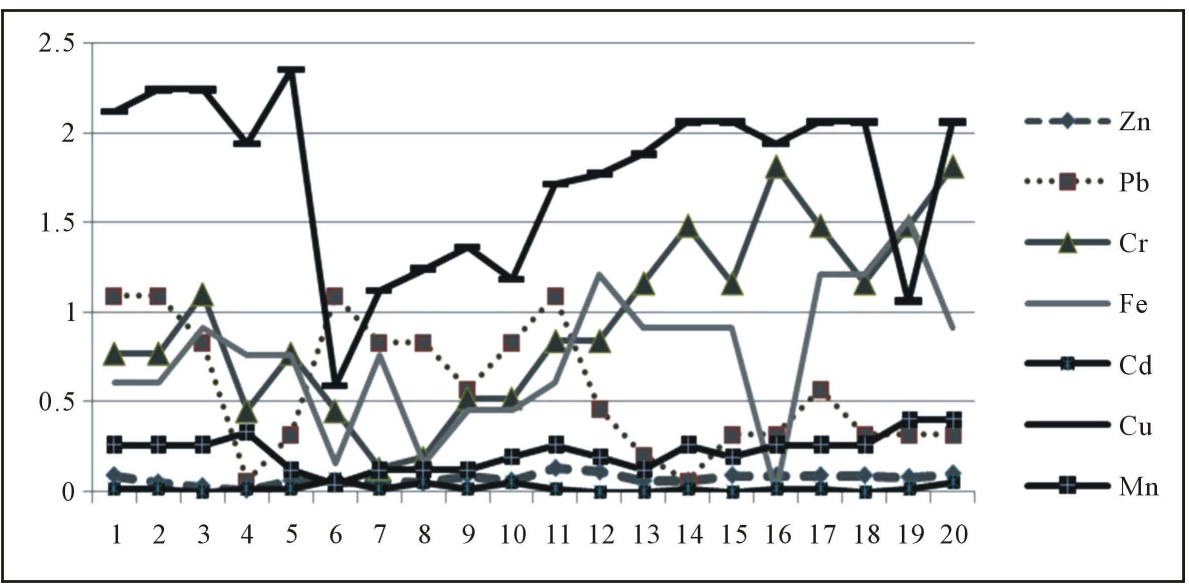

Figure 6. Variation of trace elements.

values are could be attributed to the corrosion effect of borehole materials in water, the redox environment in groundwater, and drainage from domestic activities.

\subsection{Lead (Pb)}

Lead concentration in natural water is mainly attributed to anthropogenic activities as it is extensively used in some pesticides such as lead arsenate. Besides, oil, grece, smoke from vehicle movements, drainage could be the important sources. Lead enters into the environment from industry, mining, plumbing, gasoline, coal, and as a water additive [36]. In the study area, $\mathrm{Pb}$ varied from 0.06 to $1.09 \mathrm{mg} / \mathrm{L}$ and all the samples are found with above the permissible limit of $0.05 \mathrm{mg} / \mathrm{L}$ WHO (2006) standard.

\subsection{Chromium (Cr)}

Presence of high concentration of Chromium (III) and heavy doses of Chromium salts even though are rapidly eliminated from the human body, could corrode the intestinal tract [37]. Chromium enters the environment from old mining operations runoff and leaching into groundwater, fossil-fuel combustion and waste incineration. The concentration of the Chromium in the study area ranged from $0.13-1.81 \mathrm{mg} / \mathrm{L}$ with average concentration of $0.94 \mathrm{mg} / \mathrm{L}$. The groundwater quality standard of Chromium desirable and maximum permissible limit (WHO) is 0.05. Higher concentrations were observed in all locations when compare to WHO standards. Highest concentrations of $1.81 \mathrm{mg} / \mathrm{L}$ were observed at locations 16, 20.

\subsection{Manganese (Mn)}

Manganese occurs naturally as a mineral from sediment and rocks or from mining and industrial waste. The excess $\mathrm{Mn}$ is due to the organic circulation by plants and leaves [38]. Excess concentrations of manganese make water distasteful to drinking with no specific toxic effects [39]. The concentration of the Manganese in our study area ranged from $0.04-0.40 \mathrm{mg} / \mathrm{L}$. The higher concentration found in location 19, 20 and low in location 6. The groundwater quality standard of Manganese desirable and maximum permissible limit (WHO) is $0.05 \mathrm{mg} / \mathrm{L}$. The manganese concentration is found less than the permissible limit of $0.05 \mathrm{mg} / \mathrm{L}$ in sample location 6 and found above the permissible limit in 19 locations but below the excessive limit of $0.5 \mathrm{mg} / \mathrm{L}$.

\subsection{Copper (Cu)}

The concentration of the Copper in our study area ranged from $0.59-2.35 \mathrm{mg} / \mathrm{L}$ with an average of $1.7 \mathrm{mg} / \mathrm{L}$. The groundwater quality standard of Copper desirable limit (WHO) is $0.05 \mathrm{mg} / \mathrm{L}$ and maximum permissible limit (excessive) is $1.5 \mathrm{mg} / \mathrm{L}$. In the study area 14 locations were found above desirable limit and 6 locations found above the excessive limit. Copper enters into water bodies mostly anthropogenic activities like metal plating, industrial and domestic waste, mining, and mineral leaching were main sources for the presences in environment. 


\subsection{Zinc (Zn)}

Zinc is found naturally in water, most frequently in areas where it is mined and from industrial waste, metal plating, and plumbing, and is a major component of sludge. The concentration of the Zinc in our study area ranged from $0.01-0.13 \mathrm{mg} / \mathrm{L}$ with an average of $0.7 \mathrm{mg} / \mathrm{L}$. The higher concentration found in location 11 and low in location 4. The ground water quality standard of Zinc desirable limit (WHO) is $5.0 \mathrm{mg} / \mathrm{L}$ and maximum permissible limit is $15.0 \mathrm{mg} / \mathrm{L}$. In the study area; all sampling locations are within the desirable limit (WHO).

\subsection{Cadmium (Cd)}

Cadmium found in low concentrations in rocks, coal, and petroleum and enters the ground and surface water may enter the environment from industrial discharge, mining waste, metal plating, water pipes, batteries, paints and pigments, plastic stabilizers, and landfill leachate.

The concentration of the Cadmium in our study area ranged from below the detected level to $0.07 \mathrm{mg} / \mathrm{L}$ with an average of $0.02 \mathrm{mg} / \mathrm{L}$. The higher concentration of $0.07 \mathrm{mg} / \mathrm{L}$ found in location 6 , and below the detected level noted in locations 3, 12, 13, 15 \& 18. The groundwater quality standard of Cadmium desirable and maximum permissible limit (WHO) is $0.01 \mathrm{mg} / \mathrm{L}$. Above the desirable and maximum permissible limit of WHO was noted remaining 15 sampling locations.

\section{Comparison with Standards}

To estimate whether the groundwater of the study area is suitable for drinking purposes, it has been compared with the standards of Beauro of Indian standards [19] [40]. The samples were analysed and compared with the prescribed standards, and the result are presented in Table 2. Among the samples, considerable numbers of samples were identified with the desirable limits of the standards of drinking purposes. Nevertheless, more than $80 \%$ of the samples have shown above the permissible limit of BIS and WHO standard for drinking water.

\section{Conclusions}

Interpretation of hydrogeochemical analysis reveals that the groundwater in study area is fresh water type and needs simple filtering techniques. The pH, EC and TDS are noticed high in most of the locations, and major ionic concentrations are quite below the drinking water standard. The sequence of abundance of the major ions is $\mathrm{Ca}^{2+}>\mathrm{Na}^{+}>\mathrm{Mg}^{2+}>\mathrm{K}^{+}$and $\mathrm{Cl}^{-}>\mathrm{SO}_{4}^{-2}>\mathrm{HCO}_{3}^{-} \ldots$ The chloride classification elucidates fresh and fresh brackish water type, which indicates the groundwater is derived from precipitations and residence time in the sub surface strata is less. The short residing time is well depicted from the Scholler classification as it has shown type I. In the study area, the dominant hydrochemical facies of groundwater are $\mathrm{Ca}^{2+}>\mathrm{Na}^{+}>\mathrm{Cl}^{-}$. The results of calculation saturation index show that the nearly all of the water samples are undersaturated with respect to carbonate (calcite, dolomite and aragonite) and sulfate (gypsum and anhydrite) minerals. The trace elements' concentration represents that except $\mathrm{Zn}$, other elements of $\mathrm{Fe}, \mathrm{Pb}, \mathrm{Cr}, \mathrm{Mn}, \mathrm{Cu}$, and $\mathrm{Cd}$ are found high and above the permissible limit of drinking water standard.

Since the groundwater is received from recent precipitations, ionic concentration by ionic base exchange and geological formation can be less. However, anthropogenic particularly wastes from commercial activities and domestic sewage can be rendered remarkable extent. The result also reveals that there is no sea water mixing in the shallow aquifers, and it can have a chance at deeper aquifers in the study area. As for as trace elements are concerned, industrial and agricultural activities are unlikely to be the major contamination sources because of the absence of these activities. The contamination of groundwater is also due to domestic waste water and sewers through subsurface drainage systems from high density residential and commercial buildings. Pollutants accumulated on road surfaces can be washed by storm or street cleansing as road runoff and finally are collected into the nearby sewage drainage.

\section{References}

[1] Ramon, L. (1993) All of Us, Environmental Education Dossiers. Vol. 4, Centre UNESCO de Catalunya, Mallorca, 285.

[2] Johnson, C.C. (1979) Land Application of Waste-An Accident Waiting to Happen.Groundwater, 17, 69-72. http://dx.doi.org/10.1111/j.1745-6584.1979.tb03277.x 
[3] Sastri, J.V.C. (1994) Groundwater Chemical Quality in River Basins. Hydrogeochemical Modeling, Lecture NotesRefresher Course, School of Earth Sciences, Bharathidasan University, Tiruchirapalli.

[4] Subba Rao, N., Gurunadha Rao, V.V.S. and Gupta, C.P. (1998) Groundwater Pollution Due to Discharge of Industrial Effluents in Venkatapuram Area, Visakhapatanam, Andhra Pradesh, India. Environmental Geology, 33, $289-294$. http://dx.doi.org/10.1007/s002540050248

[5] Elango, L., Kannan, R. and Kumar, S. (2003) Major Ion Chemistry and Identification of Hydrochemical Processes of Groundwater in a Part of Kancheepuram District, Tamil Nadu, India. Journal Environmental Geosciences, 10-14, 157166.

[6] Krishnakumar, S. (2004) Quality Characterization and Geochemical Characteristics of Lower Gadilum River Basin, Tamil Nadu, India. Dissertation, University of Madras.

[7] Jeevanandam, M., Kannan, R., Srinivasalu, S. and Rammohan, V. (2006) Hydrogeochemistry and Groundwater Quality Assessment of Lower Part of the Ponnaiyar River Basin, Cuddalore District, South India. Environmental Monitoring and Assessment, 132, 263-274.

[8] Mala, V. (1997) Study of the Environmental Hydrogeochemical and Sedimentological Aspects between Puduchatram to Chidambaram Area, Cuddalore District, East Coast of India. Phil Dissertation, Annamalai University, 146.

[9] Chandrasekaram, D. (1989) Hydrogeochemical Study of Coastal Groundwaters of Kerala. Indian Academy of Sciences (Earth and Planetary Sciences), 98, 287-295.

[10] Ramanathan, A.L., Mani, R., Manoharan, K., Kesavan, S. and Kathiresan, R.M. (1998) Hydrogeochemical Studies of Coastal Groundwaters from Cuddalore to Puduchatiram. Indian Journal of Marine Sciences, 27, 167-172.

[11] PWD (2000) Groundwater Perspectives: A Profile of Cuddalore District, Tamil Nadu. State Ground and Surface Water Resources Data Centre, Water Resources Organisation in Public Work Department, Government of Tamil Nadu, Chennai, 89.

[12] Schoeller, H. (1967) Qualitative Evaluation of Groundwater Resources (In Methods and Techniques of Groundwater Investigation and Development. Water Resource Series, 33, 44-52.

[13] Palmquist, W.M. (1973) Sampling for Groundwater Quality Investigations. Groundwater Studies, 125, 14.

[14] Chidambaram, S., Ramanathan, A.L., Srinivasamoorthy, K. and Ananthan, P. (2004) WATCLAST-A Computer Program for Hydrogeochemical Studies, Recent Trends in Hydrogeochemistry (Case Studies from Surface and Subsurface Waters of Selected Countries). Capital Publishing Company, New Delhi, 203-207.

[15] Prasad, B.V. and Rameshchandra, P. (1997) Groundwater Quality in an Industrial Zone. Pollution Research, 16, 105107.

[16] Tripathi, J.K. (2003) Groudwater Hydrochemistry in and around Bhanjabihar, Ganjam District (Orissa). Pollution Research, 22, 185-188.

[17] Aravindan, S., Manivel, M. and Chandrasekar, S.V.N. (2004) Ground Water Quality in the Hard Rock Area of Gadilam River Basin, Tamil Nadu. Journal of Geological Society of India, 63, 625-635.

[18] Hedge, G.V. (2006) Evaluation of Chemical Quality of Groundwater Resource in Dharwad District, Karnataka. Journal of Geological Society of India, 67, 47-58.

[19] WHO (2006) Guidelines for Drinking Water Quality. Volume 1, Recommendations, World Health Organisation, Geneva.

[20] Freeze, A. and Cherry, J. (1979) Groundwater. Prentice-Hall, Englewood Cliffs, 604 p.

[21] Garrels, R.M. (1976) A Survey of Low Temperature Water Mineral Relations. In: Interpretation of Environmental Isotope and Hydrogeochemical Data in Groundwater Hydrology, International Atomic Energy Agency, Vienna, 65-84.

[22] Prasad, R.N., Chandra, R. and Tiwari, K.K. (2008) Status of Groundwater Quality of Lalsot Urban Area in Dausa District, Rajasthan. Nature Environment and Pollution Technology, 7, 377.

[23] Stuyfzand, P.T. (1989) A New Hydrochemical Classification of Water Types with Examples of Application. AHS, 184, 89-98.

[24] Walton, W.C. (1970) Groundwater Resource Evaluation. McGraw Hill Book Co., New York, 664 p.

[25] Piper, A.M. (1944) A Graphical Procedure in the Chemical Interpretation of Ground Water Analyses. Transactions, American Geophysical Union, 25, 914-923. http://dx.doi.org/10.1029/TR025i006p00914

[26] Ryzner, J.W. (1944) A New Index for Determining Amount of Calcium Carbonate Scale Formed by a Water. Journal of American Water Works Association, 36, 472-486.

[27] Sankar, K. (1995) Hydrological Studies in the Kanyakumari District, Tamil Nadu. Unpublished PhD Thesis, University of Madras, Chennai, 90-91.

[28] Balasubramanian, A. (1986) Hydrogeological Investigations in the Tambaraparani River Basin, Tamilnadu. Unpub- 
lished PhD Thesis, University of Mysore, Mysore, 348 p.

[29] Langmuir, D. (1997) Aqueous Environmental Geochemistry. Prentice-Hall, Inc., Englewood Cliffs, 601.

[30] Drever, J.I. (1997) The Geochemistry of Natural Waters. Prentice-Hall, Englewood Cliffs, 436.

[31] Coetsiers, M. and Walraevens, K. (2006) Chemical Characterization of the Neogene Aquifer, Belgium. Hydrogeology Journal, 14, 1556-1568. http://dx.doi.org/10.1007/s10040-006-0053-0

[32] Garrels, R.M. and Mackenzie, F.T. (1971) Evolution of Sedimentary Rocks. W.W. Norton and Company, Inc., New York, 397 p.

[33] Stumm, W. and Morgan, J.J. (1981) Aquatic Chemistry: An Introduction Emphasizing Chemical Equilibria in Natural Waters. Wiley-Interscience Publication, John Wiley and Sons, New York, 780 p.

[34] Alabdula’aly, A.I., Al Zarah, A.I. and Khan, M.A. (2011) Assessment of Trace Metals in Groundwater Sources Used for Drinking Purposes in Riyadh Region. International Journal of Water Resources and Arid Environments, 1, 5-9.

[35] Ramakrishnan, S. (1998) Groundwater. Ramakrishnan Publishing, Chennai, 761.

[36] Reddy, T.B., Ramana, C.V., Bhaskar, C. and Chandrababu, P.J. (2012) Assessment of Heavy Metal Study on Ground Water in and Around Kapuluppada MSW Site, Visakhapatnam, AP. International Journal of Science and Nature, 3, 468-471.

[37] Akoteyon, S.I. and Soladoye, O. (2011) Statistical Study of Physicochemical Characteristics of Wastewater in Odogunyan, Lagos, Nigeria. E-Journal of Chemistry, 8, 2010-2015. http://dx.doi.org/10.1155/2011/787839

[38] Longe, E.O. and Enekwechi, L.O. (2007) Investigation on Potential Groundwater Impacts and Influence of Local Hydrogeology on Natural Attenuation of Leachate at a Municipal Landfill. International Journal of Environmental Science and Technology, 4, 133-140. http://dx.doi.org/10.1007/BF03325971

[39] BIS (2003) Indian Standard Drinking Water Specifications IS 10500:1991, Edition 2.2 (2003-2009). Bureau of Indian Standards, New Delhi.

[40] Offiong, O.E. and Edet, A.E. (1998) Water Quality Assessment in Akpabuyo, Cross River Basin, South-Eastern Nigeria. Environmental Geology, 34, 167-174. http://dx.doi.org/10.1007/s002540050268 